UDC 341.17

DOI https://doi.org/10.32837/apdp.v0i89.3192

P. V.Otenko

\title{
TWO SIDES OF THE CONTEMPORARY SYSTEM OF QUASI-LEGISLATIVE ACTS OF THE COMMISSION OF THE EUROPEAN UNION
}

Formulation of the problem. Commission of the EU is one of the most significant and the oldest institutions within the European Union. According to Art. 17 of the Treaty on European Union the Commission shall promote the general interest of the Union and take appropriate initiatives to that end.

In order to carry out this task duly, under Art. 290, 291 of the Treaty on the Functioning of the European Union the Commission of the EU is entitled to enact two types of quasi-legislative acts: implementing and delegated acts.

Commission's implementing and delegated acts play a vital role in the EU everyday life. However, abusive application by the European legislator of the system of delegation of quasi-legislative powers to the Commission may cause adverse effects on the EU legal order.

Thus, it is important to outline both advantages and disadvantages of the modern system of Commission's delegated and implementing acts in order to find out the real impact of such acts on the EU legal order.

Analysis of the latest researches and publications. The issue of Commission's implementing and delegated acts has been partially outlined in scientific papers of such scholars as Steve Peers, Marios Costa, Carlo Tovo, Paul P. Craig, Zamira Xhaferri, Fabio Franchino, Herwig Hofmann, Thomas Christiansen, Mathias Dobbels and others. Nevertheless, most scholars limited their attention only to negative aspects of the system of Commission's quasi-legislative acts, when the benefits of having such system within the EU have not been fully outlined.

Formulation of the aim and objectives of the article. The aim of the scientific article is to make a general analysis of both advantages and disadvantages of the contemporary system of Commission's quasi-legislative acts. In order to achieve the aim, the following objectives have been set: to point out advantages of Commission's quasi-legislative acts; to analyze advantages of Commission's quasi-legislative acts; to emphasize disadvantages of Commission's quasi-legislative acts; to examine disadvantages of Commission's quasi-legislative acts.

Basic research material. The modern system of Commission's implementing and delegated acts is significant for the EU for a number of reasons. It is possible to outline the following principal advantages: acceleration of the EU decision-making process; making the EU decision-making process more flexible; improvement of the quality of the EU legislation; unloading the EU legislature's workload, i.e. the EU Parliament and the Council.

Most EU legislative acts are enacted under the ordinary legislative procedure pursuant to Art. 294 of the TFEU. According to the latest activity report on developments 
and trends of the ordinary legislative procedure made by the European Parliament's officials, the average length of procedure for acts adopted at first reading is from 18 to 20 months [1, p. 4]. Additionally, in its previous activity report on the ordinary legislative procedure it was stated that several months should elapse until the act concerned is ready for the adoption, because it must be translated into all official languages, then verified by the lawyer-linguists. This final step usually takes about 8 weeks or 2 months [2, p. 12]. Thus, in order to adopt just one EU legislative act under the ordinary legislative procedure it takes about 2 years of the EU legislator work.

In its turn, the adoption of implementing and delegated acts by the Commission takes approximately from 3 to 5 months which is in 4 times faster than the adoption of EU legislative acts under the ordinary legislative procedure [3, p. 217].

Secondly, due to the COVID-19 outbreak within the EU in the beginning of 2020, the Commission has just within two months adopted a vast number of implementing acts on different areas (health, economy, research, budget, etc.) in order to provide Member States, individuals and legal entities with newly adjusted legal norms and rules.

In such a way, the system of the Commission's implementing and delegated acts let the Commission on behalf of EU make necessary decisions in a fast and effective manner.

The third benefit for the delegation of quasi-legislative powers to the Commission is improvement of the quality of the EU legal acts. Under the Founding EU Treaties, the EU is granted with a power to adopt legal acts in areas that are explicitly specified in Art. 3 and 4 of the TFEU. There are currently 16 different areas in the list. Consequently, it is impossible for the EU legislator to envisage all detailed rules and procedures to govern certain legal relationships in an area concerned within the basic EU legislative act.

Delegated acts adopted by the Commission mostly outline detailed rules, procedures and criteria to be applied within the particular area. Implementing acts also provide Member States with 'guidelines' in different policy areas. Both implementing and delegated acts help to govern effectively legal relations within the area concerned via making a clear and experienced assessment by the high-quality staff.

In the report from the Commission on the working of committees during 2018, the total number of committees was 275 within 28 different policy sectors [ $4, \mathrm{p} .3]$. In its turn, each committee is composed of representatives of the Member States, chaired by a representative of the Commission and regardless of the procedure applied a committee delivers its opinion. Delegated acts are adopted by the Commission. External expert groups composed of representatives of different stakeholders help to make an expertise of a delegated act concerned.

Having such a big number of specialized staff helps the EU to have an effective system of quasi-legislative legal acts which are drafted on a purely professional basis.

The fourth rational for the delegation of quasi-legislative powers to the Commission is reduction of the workload of the EU legislator [5, p. 105]. As it was confirmed in the Schengen borders code judgment the EU legislator are entitled to adopt legislative acts that have more political dimension. Delegation of quasi-legislative powers to the Commission provides the EU legislator with necessary time to solve issues of greater 
significance. Delegated and implementing acts allow the EU legislator to concentrate on the core legislative work (framework legislation) and to shift more technical details to the level of technical experts in consultation with or assistance by Member States' representatives and other sources of expertise [3, p. 217].

From the other side, there are also some drawbacks within the contemporary system of Commission's implementing and delegated acts.

The first one is the absence of a clear legal distinction between implementing and delegated acts. In 2009 the Lisbon Treaty specified a clear system of hierarchy of EU legal acts within the EU legal order. In a simple way, the TFEU distinguishes between purely legislative legal acts adopted under the ordinary or special legislative procedures, quasi-legislative acts (delegated acts) and purely executive acts (implementing acts).

Commission's delegated acts are aimed to amend or supplement certain non-essential elements of a basic legislative act concerned. At the same time, Commission's implementing acts also amend provisions of a basic legislative act in some extent, since they usually set up particular criteria or detailed rules to be applied within the EU.

Implementation involves the uniform interpretation of basic acts' provisions. This official interpretation is prepared by the Commission in the form of uniform conditions specified in implementing acts. In this respect, it is possible to say that such uniform conditions also make amendments in basic legislative acts, because they explicitly set out missing criteria and rules that should be applied by Members States in the same way.

The lack of a clear distinction between implementing and delegated acts not only undermines the hierarchy of EU legal acts set up by the Lisbon Treaty, but also has an influence on the application of a particular system of institutional oversight made by the EU legislator.

Furthermore, the lack of a clear distinction between these two kinds of legal acts in practice gives rise to the number of interinstitutional disputes. In this regard, the CJEU provides EU institutions with the interpretation on the issue when implementing or delegated acts should be invoked. The CJEU emphasized that the EU legislator has a discretion when it decides to confer a delegated power on the Commission pursuant to Art. 290 (1) of the TFEU or an implementing power pursuant to Art. 291 (2) of the TFEU [6].

The second possible adverse effect of Commission's implementing and delegated acts is the breach of the principle of institutional balance. The principle of institutional balance in the EU implies that each of its institutions has to act in accordance with the powers conferred on it by the Treaties, in accordance with the division of powers [7].

An excessive delegation of quasi-legislative powers by the EU legislator to the Commission may lead to the breach of the principle of institutional balance. Sometimes Commission abuses its quasi-legislative powers by replacing the EU legislator. Such practice not solely breaches the founding principles of a clear distinction of powers between the Commission and the EU legislator (Council and European Parliament) which has an exclusive right to adopt binding EU legislative act but also leads to numerous interinstitutional disputes and litigations. 
In this respect, Case-286/14 EP $v$. Commission is a great example of disputes regarding the problem of limitation of delegation powers. In 2013 Regulation 1316/2013 (basic act) conferred on the Commission the power to 'detail' funding priorities within this facility. Nevertheless, the text of the basic act does not specify whether the Commission should amend or supplement the basic act. Later on, the Commission adopted Delegated Regulation $275 / 2014$ by adding the funding priorities to an annex of the basic act.

The European Parliament filed a claim to the CJEU and stated that the Commission was granted a power solely to supplement, not amend the basic act concerned and sought to annul the Delegated Regulation 275/2014. The CJEU ruled that the power to supplement or amend a basic act should be determined by the EU legislator and cannot be determined by the Commission itself. Moreover, the CJEU held that Commission should adopt a separate act when exercising its supplementing power [8].

Thus, it would be worrying, for example, if the power of delegation would allow the Commission to rewrite or amend most EU legal acts without Council and European Parliament being involved in such process. The widespread granting of such powers raises question of democratic accountability as it supplants the legislative process $[9, \mathrm{p} .14]$.

The third drawback of the modern system of Commission's implementing and delegated acts is the lack of accountability. Accountability is now considered to be an essential feature, if not the most important one, of any system of the public governance. In the EU, the term accountability usually associates with the term 'democratic deficit'. The 'democratic deficit' is a condition when the EU institutions, bodies and agencies, except the European Parliament, are lack of transparency mainly because they are not directly elected by the EU citizens.

The Lisbon Treaty has separated Commission's delegated acts from the comitology procedure. The abolishment of comitology for delegated acts released Commission from the formal control mechanism of national representatives from Member States to which the Commission was bound in a pre-Lisbon setting. Moreover, both the Council and the European Parliament lost the flow of detailed information that was previously generated in the context of comitology committees, and which was necessary to ensure effective control of the Commission's powers [10, p. 455].

The Common understanding between the Commission, the European Parliament and the Council on delegated acts which came into force in 2016 only sets out that 'the Commission shall consult experts designated by each Member State in the preparation of draft delegated acts'. However, unlike comitology committees, expert groups are not subject to any transparency and accountability standards, and very little is known about their number, composition and meetings [10, p. 454].

As to implementing acts, alterations and innovations made by the latest comitology Regulation 182/2011 have not solved the problem of Commission's accountability. According to provisions of Regulation 182/2011, Commission is obliged to provide both the Council and the European Parliament with draft implementing acts on which the committees are asked to deliver an opinion and the final draft implementing acts following delivery of the opinion of the committees [11]. 
Although the European Parliament and the Council enjoy the scrutiny right under Regulation 182/2011, Commission just shall review the draft implementing act, taking into account of the positions expressed, and, subsequently, inform the European Parliament and the Council whether it intends to maintain, amend or withdraw the draft implementing act. In this respect, the scope of the right to scrutiny is very limited, since it extends only to situations when a basic act is adopted under the ordinary legislative procedure. The right of scrutiny cannot be applied when a basic act is enacted either under special legislative procedure or when an implementing act concerned was adopted on the basis of delegated act.

All the mentioned-above illustrates that procedures applied to Commissions' implementing and delegated acts are not enough transparent and accountable to the EU legislator and EU citizens. Such situation puts at stake the legitimacy of Commissions' implementing and delegated acts.

Conclusions. Contemporary system of Commission's implementing and delegated acts have both positive and negative impact on the EU legal order.

From the one hand, Commission's implementing and delegated acts provide the EU with great opportunities to make urgent and necessary decisions in a fast and effective manner. Nowadays it is vital to duly react and govern legal relationships in newly emerged situations. Such acts also help the EU to maintain efficient and highly-grade system of quasi-legislative legal acts which are prepared on a purely professional basis. Finally, the delegation of quasi-legislative powers to the Commission greatly reduces the workload of the EU legislator and let it concentrate on the more important political issues.

From the other side, there is an absence of a clear legal distinction between Commission's implementing and delegated acts in practice. Such situation undermines the hierarchy of EU legal acts set up by the Lisbon Treaty, has an influence on the application of a particular system of institutional oversight by the EU legislator and also leads to numerous interinstitutional litigations. Secondly, the Commission quite often abuses the right to adopt delegated acts, which leads to the breach of the principle of institutional balance. Eventually, due to the lack of transparency and accountability of procedures applied to Commission's implementing and delegated acts the question of legitimacy should be put at stake.

\section{References}

1. Activity report: Developments and trends of the ordinary legislative procedure (1 July 2014 1 July 2019 ( $8^{\text {th }}$ parliamentary term). URL : https://www.europarl.europa.eu/cmsdata/198024/activityreport-2014-2019_en.pdf (Last accessed: 10.02.2021).

2. Activity report on the Ordinary Legislative Procedure (4 July 2014 - 31 December 2016 ( $8^{\text {th }}$ parliamentary term). URL : https://www.europarl.europa.eu/cmsdata/198143/Activity-reportordinary-legislative-procedure-2014-2016-en.pdf (Last accessed: 10.02.2021).

3. Szapiro M. The European Commission: A practical guide. London; London: John Harper Publishing, 2013. $378 \mathrm{p}$.

4. Report from the Commission on the working of committees during 2018. URL: https://ec.europa.eu/ transparency/regdoc/rep/1/2019/EN/COM-2019-638-F1-EN-MAIN-PART-1.PDF (Last accessed: 10.02.2021).

5. Majone G. Two logics of delegation: agency and fiduciary relations in EU governance. European Union Politics. 2001. Vol. 2(1). P. 103-122. 
6. Judgment of the Court (Grand Chamber) of 18 March 2014. European Commission v European Parliament and Council of the European Union. Case C-427/12. ECLI identifier: ECLI:EU:C:2014:170.

7. Glossary of summaries - institutional balance. URL: https://eur-lex.europa.eu/summary/glossary/ institutional_balance.html (Last accessed: 10.02.2021).

8. Judgment of the Court (Fifth Chamber) of 17 March 2016. European Parliament v European Commission. Case C-286/14. ECLI identifier: ECLI:EU:C:2016:183.

9. Cini M. The European Commission: An unelected legislator? The Journal of Legislative Studies. 2002. Vol. 8:4. P. 14-26.

10. Peers S., Costa M. Accountability for Delegated and Implementing Acts after the Treaty of Lisbon. European Law Journal. 2012. Vol. 18(3). P. 427-460.

11. Regulation (EU) No 182/2011 of the European Parliament and of the Council of 16 February 2011 laying down the rules and general principles concerning mechanisms for control by Member States of the Commission's exercise of implementing powers. OJ L 55. 28.2.2011. P. 13-18.

\section{Summary}

Otenko P. V. Two sides of the contemporary system of quasi-legislative acts of the Commission of the European Union. - Article.

The scientific article is devoted to the issue of complex legal analysis of both advantages and disadvantages of the contemporary system of Commission's quasi-legislative acts which is composed of implementing and delegated acts. Commission's implementing and delegated acts play a crucial role in the EU, but the abusive application by the EU legislator of the delegation of quasi-legislative powers to the Commission of the EU cause various negative consequences on the EU legal order. The author outlines the following positive sides of Commission's quasi-legislative acts: acceleration of the EU decision-making process, adding the EU decision-making process flexibility, improvement of the quality of the EU legislative acts and unloading the overall EU legislature's workload. Taking into account the latest statistics, the author has proved that the process of the adoption of implementing and delegated acts is in four times faster than ordinary and special legislative procedures. It is emphasized that COVID-19 outbreak in 2020 made the EU urgently enact a bunch of legislative acts that were mainly adopted in the form of Commission's quasi-legislative acts. The author also points out that the quality of the EU's legislation has been improved as well as EU's legislator workload has been greatly reduced because of Commission's implementing and delegated acts. At the same time, the author specifies that the absence of an explicit legal distinction between Commission's implementing and delegated acts leads to numerous interinstitutional litigations and disputes and undermines the hierarchy of legal acts under the provisions of the Lisbon Treaty. It is established that an excessive application by the Commission of the EU of the quasi-legislative instruments may breach the principle of institutional balance and may lead to the replacement of the sole EU legislator the European Parliament and the Council. Eventually, the author argues that the lack of transparence and accountability of the Commission of the EU during the process of adoption of implementing and delegated acts deepen the 'democratic deficit' problem within the EU.

Key words: European Union, implementing acts, delegated acts, benefits, drawbacks, EU legislator, European Commission.

\section{Анотація}

Отенко П. В. Дві сторони сучасної системи квазізаконодавчих актів Комісії Свропейського Союзу. - Стаття.

Наукова стаття присвячена комплексному юридичному аналізу переваг та недоліків сучасної системи квазізаконодавчих актів Комісії $\mathrm{CC}$, що складається з таких видів актів, як імплементаційні та делеговані. Імплементаційні та делеговані акти Комісії відіграють дуже важливу роль в ЄС, однак надмірне та часте використання механізму делегування квазізаконодавчих функцій Комісії ЄС з боку законотворця $\mathrm{CС} \mathrm{спричиняє} \mathrm{різноманітні} \mathrm{негативні} \mathrm{наслідки} \mathrm{для} \mathrm{правопорядку} \mathrm{ЄС.} \mathrm{Автор} \mathrm{виокремлюе}$ такі переваги системи квазізаконодавчих актів Комісії $\mathrm{CC}$ : прискорення процесу прийняття рішень на рівні $\mathrm{CC}$; надання процесу прийняття рішень на рівні ЄС більшої гнучкості; покращення якості законодавчих актів $\mathrm{CC}$, а також зменшення робочого навантаження на законотворця ЄС. Беручи до уваги останні статистичні дані, автор стверджує, що процес прийняття Комісією $Є$ С імплементаційних та делегованих актів $\epsilon$ в чотири рази швидшим, ніж прийняття законодавчих актів за результатами звичайної та спеціальної законодавчої процедури. Зазначається, що спалах COVID-19 в 2020 році змусив $€ \mathrm{C}$ швидко прийняти велику кількість законодавчих актів, які у своїй переважній більшості були 
прийняті у формі квазізаконодавчих актів Комісії. Автор також підкреслює, що якість законодавства ЄС покращилась, а робоче навантаження на законотворця ЄС було зменшено саме завдяки імплементаційним та делегованим актам Комісії ЄС. Автор зазначає, що відсутність чіткого юридичного розмежування між імплементаційними та делегованими актами Комісії призводить до великої кількості міжінституційних суперечок та судових спорів, а також підриву ієрархії правових актів відповідно до положень Лісабонського Договору. Доведено, що надмірне застосування Комісією ЄС квазізаконодавчих інструментів може порушити принцип інституційного балансу та може призвести до заміни єдиного законотворця ЄC - Європейського Парламенту та Ради. Підсумовуючи, автор стверджує, що недостатність відкритості та підзвітності Комісії ЄС під час процесу прийняття імплементаційних та делегованих актів посилює проблему «дефіциту демократії» в ЄС.

Ключові слова: Європейський Союз, імплементаційні акти, делеговані акти, переваги, недоліки, законотворець ЄС, Європейська Комісія. 